\title{
On the Significance of Development Banks in the Economies of Post-Soviet Countries
}

\author{
Azer M. Safarov ${ }^{1}$ \\ 1 Department of Banks \& Bank Management, Financial University under the Government of the Russian \\ Federation,School of Management, Moscow, Russian Federation \\ Correspondence: Azer M. Safarov, Department of Banks \& Bank Management, Financial University under the \\ Government of the Russian Federation, Moscow, Russian Federation. Tel: 7-495-615-7275. E-mail: bibm@fa.ru
}

\author{
Received: March 11, 2015 Accepted: April 10, 2015 Online Published: May 25, 2015 \\ doi:10.5539/res.v7n10p53 URL: http://dx.doi.org/10.5539/res.v7n10p53
}

\begin{abstract}
After the collapse of the Soviet Union, each of the new countries which obtained sovereignty had to create a new economy and the respective banking system, as well as to establish international financial and economic relationship in order to ensure progressive social and economic development. The article analyzes the role of international and national development banks for the post-Soviet countries. The main conclusion is that international development banks made certain positive contribution to this process. However, the lack of own development banks, tendencies of the commercialization of state banks and general weakness of banking systems in the post-Soviet countries in terms of resources, along with mistakes in economic reforms, are the factors which give rise to economic problems and hinder further economic and social development in these countries. Establishing and strengthening national and regional development banks can be an important factor for such development.
\end{abstract}

Keywords: development banks, bank politics, institutional structure of banking system, post-Soviet countries

\section{Introduction}

Over the past years, the role of development banks and prospects of their future activities has been a matter of debates in scientific, banking and political communities. Back in 2000, the US Congress Committee discussed the transfer of IBRD credit activities to regional development banks (Johannes). Some proponents of market economy argue that international development banks have already accomplished their role, and their significance, scope and efficiency of activities is gradually decreasing in the new architecture of global financial system (Johannes). Based on the analysis of the activity as to one of the largest banks, the Brazilian Development Bank, a group of experts has come to the conclusion that, even at national level, the adoption of decisions on financing the projects is associated with political relations of companies rather than with the efficiency of their projects (Ismaylov \& Papava, 2012). At the same time, it is suggested that the accretion of power of international development banks, the refocusing of their activities from poverty reduction to sustainable economic growth and global financial stability, the authorization of a bigger share in their funds and governing bodies of new developing countries with large potential can significantly increase the contribution of these banks into social progress (Johannes; Harvard school of economy, 2011).

Choosing the post-Soviet countries as a research subject, we are aware of considerable conditionality of such a choice. The point is that, being in fact a part of the Russian Empire, and later of the Soviet Union, the peoples of these countries have borrowed a lot of common things from Russian culture, administration, and management system. Later, at the collapse of the Soviet system and economic reforms, these countries often copied forms and methods of market reforms implemented in Russia. Thus, common features of transitional economy have been maintained and expanded in these countries. At the same time, painful processes of the collapse of the Soviet Union, social and economic situation in Russia itself, and the subsequent mistakes of Russian policy towards these countries have forced them to look for allies in other centers of concentration of political and economic power. As a result, by the beginning of the 2000's, some serious discrepancies in social, economic and political orientation of these countries took place. Currently, all Baltic states are members of the European Union and NATO; among the countries of the Caucasus, Georgia withdrew from the CIS, having concluded the agreement of association with the European Union, and set a course to joining NATO; Armenia withdrew from the association with the European 
Union and joined the Eurasian Union. Azerbaijan keeps pursuing independent policy, while striving to maintain balanced relationship with both Western countries and Russia; in Central Asia, Kazakhstan, Kyrgyzstan and Tajikistan joined the Eurasian Union, while striving to maintain consistent relationship with Western countries. Turkmenistan and Uzbekistan strive to pursue relatively independent policy; in the Eurasian part of the former Soviet Union, Belarus signed the Union Treaty with Russia and joined the Eurasian Union, Moldova signed the agreement of association with the European Union; at present, tragic events take place in Ukraine, where civil war has been initiated and still continues, due to the impossibility of any civilized solutions to the problems of political guidance and the formula of economic interaction between Eastern and Western countries. Attempts to use these contradictions in global political game, along with lop-sided assessment of Ukrainian conflict by international organizations pushed Europe back to the Cold War period and cranked up tensions among the countries of the former Soviet Union.

Taking into consideration political and economic processes in the post-Soviet space in recent years, as well as controversial nature and incompleteness of these processes, we decide to choose quite a conditional classification of these countries:

(a) Baltic states, which joined economic and political system of the Western and Central Europe;

(b) Other countries, the former members of the CIS, being currently in various types of relationship with each other. The topic and subject matter of our research is the second group of countries and the activities of national and international development banks in these countries.

The relevance of the research topic is associated with the significance of development institutions for solving socio-economic problems in developing countries, which include the post-Soviet countries.

The recovery of political sovereignty for all republics of the former Soviet Union proved costly, in literal sense. Mistakes in economic reforms prescribed by liberal monetary economics led to the disruption of economic links settled over decades, as well as wild privatization, price shocks, exchange swings, heavy decrease in the investment and GDP put the clock back for the economies of these countries and, as a result, for the entire social welfare, for decades.

Meanwhile, over the past decades, gravity center in the world's economics has moved from economic growth concept towards the concept of sustainable economic growth. In s context, the reasonability of economic growth at any cost and GDP as the main index of economic growth is brought into a question. According to this concept, balanced growth of national wealth, including productive, human and natural capital of a country, ensuring human welfare now and in the long term, should be a guideline for economic behavior and economic policy at all levels of economic management. Based on this, UN group of experts elaborated methods for estimating real wealth and made the evaluation based on 20 world's leading countries for the period of 1990 to 2008, which was represented at the UN Conference on Sustainable Development in 2012. According to the findings of this analysis, the share of human capital was 70 to $80 \%$ in the structure of national wealth in the developed countries; the share of productive capital (fixed assets) took the second place, and the share of natural capital was expressed in small numbers (The Stieglitz's Report, 2012). These data show once again the need for rational structure of national economy, the avoidance of any gaps in social life of developing countries, which include the post-Soviet countries as well. However, low production profitability, weak income basis of budgets, the underdevelopment of the countries' own banking system, challenges regarding its optimal structure, and weak resource base became the significant obstacles to banking support of economic and social development in the post-Soviet countries. In these circumstances, their appeal to the existing international financial and banking institutions for assistance was quite natural. Therefore, in the early 90's, the entry of these countries into the IMF and the World Bank Group, which started to provide technical and financial assistance to the post-Soviet countries, took place.

The next step was the entry of the post-Soviet countries into international and regional development banks, among which the European Bank for Reconstruction and Development (EBRD), the Asian Development Bank (ADB), and the Islamic Development Bank (IDB) should be mentioned separately. In addition, these countries started direct cooperation with a number of transnational banks and funds, such as the Japan Bank for International Cooperation (JBIC), the US and Turkish Eximbanks, ABN AMRO Bank, the German Reconstruction Loan Corporation (KfW), the Black Sea Trade and Development Bank (BSTDB), the Kuwait Fund for Arab Economic Development, the Saudi Fund for Development, the International Fund for Agricultural Development (IFAD), the OPEC Fund for International Development, the Abu Dhabi Fund for Development, etc.

The loans received from these institutions have played significant role in the revival of economies of the post-Soviet countries, meeting their needs for financial resources, the acceleration of economic reforms, the achievement of macroeconomic stability, the enhancement of governmental control, the stimulation of the 
development as to certain industries, the rehabilitation of infrastructure, and the generation of new jobs. Cooperation with international and regional financial and economic institutions contributed to the integration of the post-Soviet countries into global economic system. Nowadays, over two decades after the restoration of independence, the strengthening of links with international financial institutions (IFIs) is still one of the major factors in social and economic development of the post-Soviet countries.

\section{Peculiarities of Investment Process in Post-Soviet Countries}

Certainly, over the past years, major components of national economies have been restored and banking systems corresponding to market economy have been created in the post-Soviet countries. However, like the rest of the world, these economies experienced severe shocks of financial and economic crises in 1998 and 2008. On the other hand, the banking systems that have been created are not strong and efficient enough yet to meet the needs of national economy in loan and investment resources. Therefore, the post-Soviet countries need efficient and comprehensive economic policies fo mobilizing all potential sources of economic growth, all means for the enhancement and improvement of banking system. Let us consider the dynamics of some indices describing investment process and bank crediting in the post-Soviet countries (see Table 1 below).

Table 1. Dynamics of GDP and fixed capital investment (percentage of the preceding year)

\begin{tabular}{|c|c|c|c|c|c|c|c|c|c|c|}
\hline Country & Index & 2005 & 2006 & 2007 & 2008 & 2009 & 2010 & 2011 & 2012 & 2013 \\
\hline \multirow[t]{2}{*}{ Azerbaijan } & IFC & 17 & 15 & 12 & & -18.4 & 21.2 & 27.3 & 18.5 & 15.1 \\
\hline & GDP & 26.4 & 34.5 & 25.0 & 10.8 & 9.4 & 4.9 & 0.1 & 2.2 & 5.8 \\
\hline \multirow[t]{2}{*}{ Armenia } & IFC & 33 & 38 & 16 & & -37.4 & -2.5 & -8.9 & -2.6 & -7.7 \\
\hline & GDP & 13.9 & 13.2 & 13.7 & 6.9 & -14.1 & 2.2 & 4.7 & 7.2 & 3.5 \\
\hline \multirow[t]{2}{*}{ Belarus } & IFC & 20 & 32 & 30 & & 4.7 & 15.8 & 17.9 & -11.7 & 9.3 \\
\hline & GDP & 9.4 & 10.0 & 8.6 & 10.2 & 0.2 & 7.7 & 5.5 & 1.7 & 0.9 \\
\hline \multirow[t]{2}{*}{ Georgia } & IFC & & & & & & & & & \\
\hline & GDP & 9.6 & 9.4 & 12.3 & 2.3 & -3.8 & 6.3 & 2.0 & 6.2 & 3.2 \\
\hline \multirow[t]{2}{*}{ Kazakhstan } & IFC & 34 & 11 & 7 & & 2.9 & -3.0 & 2.9 & 4.1 & 6.9 \\
\hline & GDP & 9.7 & 10.7 & 8.9 & 3.3 & 1.2 & 7.3 & 7.5 & 5.0 & 6.0 \\
\hline \multirow[t]{2}{*}{ Kyrgyzstan } & IFC & 6 & 55 & 65 & & 30.8 & -9.2 & -3.1 & 42.1 & 7.5 \\
\hline & GDP & -0.2 & 3.1 & 8.5 & 8.4 & 2.9 & -0.5 & 6.0 & -0.1 & 10.5 \\
\hline \multirow[t]{2}{*}{ Moldova } & IFC & 12 & 17 & 44 & & -33.5 & 22.6 & 12.5 & -1.1 & 1.5 \\
\hline & GDP & 7.5 & 4.8 & 3.1 & 1.4 & -4.7 & 7.1 & 6.8 & -0.7 & 8.9 \\
\hline \multirow[t]{2}{*}{ Russia } & IFC & 11 & 14 & 20 & & -13.5 & 6.3 & 10.8 & 6.8 & -0.2 \\
\hline & GDP & 6.4 & 8.2 & 8.5 & 5.2 & -7.8 & 4.5 & 4.3 & 3.4 & 1.3 \\
\hline \multirow[t]{2}{*}{ Tajikistan } & IFC & 12 & 55 & 112 & & -17.8 & 12.6 & 2.8 & -23.3 & 17.2 \\
\hline & GDP & 6.7 & 7.0 & 7.8 & 7.9 & 3.8 & 6.5 & 7.4 & 7.5 & 7.4 \\
\hline \multirow[t]{2}{*}{ Turkmenistan } & IFC & & & & & & 14.1 & 23.2 & 38.0 & 7.1 \\
\hline & GDP & 13.0 & 11.0 & 11.1 & 14.7 & 6.1 & 9.2 & 14.7 & 1.1 & 10.2 \\
\hline \multirow[t]{2}{*}{ Ukraine } & IFC & 2 & 19 & 32 & & -41.5 & -0.6 & 18.9 & 8.3 & -11.1 \\
\hline & GDP & 2.7 & 7.3 & 7.9 & 2.3 & -14.8 & 4.2 & 5.2 & 0.2 & 1.9 \\
\hline \multirow[t]{2}{*}{ Uzbekistan } & IFC & 7 & 9 & & & 24.8 & 9.2 & 7.9 & 12.7 & 9.8 \\
\hline & GDP & 7.0 & 7.3 & 9.5 & 9.0 & 8.1 & 8.5 & 8.3 & 8.2 & 8.0 \\
\hline
\end{tabular}

Source: Finances investment and prices of the Commonwealth of Independent States/Statistical abstract/Moscow, 2007. Finances investment and prices of the Commonwealth of Independent States/Statistical abstract/Moscow, 2014.

Note. IFC - Investment to fixed capital. GNP — Gross national product. 
The analysis of the data from Table 1 shows considerable differences among the countries in the dynamics of investment and GDP growth. The highest values of these indices are observed in such countries as Azerbaijan, Belarus, Kazakhstan and Turkmenistan. The lowest indices are in Ukraine, Moldova and Russia.

Table 2. Structure of financing sources for fixed asset investment

\begin{tabular}{|c|c|c|c|c|c|c|c|c|}
\hline \multirow[t]{2}{*}{ Country } & \multirow[t]{2}{*}{ Total \% } & \multicolumn{7}{|c|}{ Including } \\
\hline & & $\begin{array}{l}\text { Budget } \\
\text { sources }\end{array}$ & $\begin{array}{l}\text { Company } \\
\text { proprietary } \\
\text { means }\end{array}$ & $\begin{array}{l}\text { Loans } \\
\text { domestic } \\
\text { banks }\end{array}$ & by & $\begin{array}{l}\text { Foreign } \\
\text { investment }\end{array}$ & $\begin{array}{l}\text { Means of the } \\
\text { population }\end{array}$ & $\begin{array}{l}\text { Other } \\
\text { sources }\end{array}$ \\
\hline Azerbaijan & 100 & 45.3 & 21.2 & 1.3 & & 26.2 & 2.6 & 3.4 \\
\hline Armenia & 100 & 17.7 & 42.4 & & & 8.5 & 28.9 & 2.5 \\
\hline Belarus & 100 & 20.7 & 37.8 & 21.3 & & 7.3 & 8.3 & 4.6 \\
\hline Kazakhstan & 100 & 16.7 & 47.0 & 20.4 & & 11.3 & 4.5 & \\
\hline Kyrgyzstan & 100 & 4.6 & 35.5 & 0.9 & & 33.8 & 22.5 & 1.7 \\
\hline Moldova & 100 & 11.4 & 56.9 & 11.0 & & 12.4 & 2.4 & 5.9 \\
\hline Russia & 100 & 19.0 & 44.5 & 15.1 & & 1.1 & & 20.3 \\
\hline Tajikistan & 100 & 42.1 & 2.8 & 29.2 & & 7.5 & & 18.4 \\
\hline Uzbekistan & 100 & 5.5 & 53.1 & 11.0 & & 20.3 & & 10.1 \\
\hline Ukraine & 100 & 5.1 & 63.8 & 15.3 & & 1.8 & 8.8 & 5.2 \\
\hline
\end{tabular}

Source: Finances investment and prices of the Commonwealth of Independent States/Statistical abstract/Moscow, 2007., Finances investment and prices of the Commonwealth of Independent States/Statistical abstract/Moscow, 2014.

Data from Table 2 show considerable difference in the structure of financing sources of investment process. The most important sources are company proprietary means (Kazakhstan, Moldova, Russia, Uzbekistan and Ukraine) and budgetary means (Azerbaijan, Tajikistan, Belarus and Russia). The common feature of the economies of all countries is minimum level of loan granting by domestic banks for fixed capital investment. Low level of bank crediting is the characteristic feature for a countries of the former Soviet Union, not only in investment sector, but also in all economic sectors, including households. This conclusion is confirmed by data from Table 3 below.

Table 3. Financial intermediation in post-Soviet countries

\begin{tabular}{llllll}
\hline Countries & GDP, $\$ \mathrm{mln}$ & Assets/GDP & Loans/GDP & Deposits/GDP & Capital/GDP \\
\hline Russia & $2,194,346.1$ & 86.0 & 48.6 & 48.4 & 10.6 \\
Kazakhstan & $223,234.2$ & 45.7 & 38.4 & 28.1 & 6.0 \\
Ukraine & $175,000.0$ & 91.4 & 65.1 & 47.8 & 13.8 \\
Azerbaijan & $79,008.8$ & 32.9 & 22.9 & 14.3 & 5.5 \\
Belarus & $71,214.0$ & 58.0 & 39.0 & 32.7 & 8.1 \\
Uzbekistan & $41,238.9$ & 48.3 & 29.2 & 28.7 & 7.2 \\
Armenia & $10,764.0$ & 67.4 & 41.1 & 35.7 & 10.4 \\
Tajikistan & $8,488.4$ & 31.2 & 17.0 & 65.0 & 30.5 \\
Moldova & $7,725.5$ & 75.5 & 40.7 & 47.2 & 11.3 \\
Kyrgyzstan & $7,115.8$ & 31.5 & 15.5 & 19.2 & 5.3 \\
\hline
\end{tabular}

Source: Banks of CIS countries. Overview 2013. Moscow. 2014. 
The significant gap in bank crediting, national economy and banking system in the post-Soviet countries in comparison with countries of Central Europe becomes evident when compared to equivalent indices of the respective countries.

\subsection{Peculiarities of Banking Policy in Post-Soviet Countries}

These circumstances require a special attitude towards banking system in the post-Soviet countries and dictate the necessity to develop and implement evidence-based banking policy. However, real banking policy in individual countries does not meet these requirements. We can observe such situation in the Russian Federation.

What are the most important features of banking policy that have been pursued in the Russian Federation over the past two decades?

1) Commercialization of state-owned banks.

In 1990's, on the wave of privatization policy, huge networks of specialized banks, such as Promstroibank, Agroprombank and Zhilsotsbank, were devastated, partially destroyed and partially reopened as smaller commercial banks. The remaining state-owned banks, such as Vneshtorgbank and Sberbank, through both formal features and internal rules of operation, started to turn more and more into commercial banks. Even Rosselkhozbank, initially intended to support the development of agricultural sector, started to operate by using grounds and rules of a commercial bank. As a result, at the expense of public means, some major banks have been established, which operate as ordinary commercial entities and do not wish to participate in solving socio-economic problems at national scale.

2) Monopolization of banking sector by commercial banks with state participation.

Banking policy openly supports this monopolism. This group of banks, both in day-to-day operation and in crisis times in particular, receives full-scale state support. It was like that in 2008, when huge monetary liquidity was pumped into these banks. This happens from time to time - once the Central Bank of the Russian Federation recalls the license of any commercial bank, simultaneous campaign is initiated, which strives to demonstrate the reliability of banks with state participation, and, vice versa, the inconsistency of a regular commercial bank.

3) Forced mergers of commercial banks

A tradition has been established in the Russian Federation to increase minimum statutory capital of commercial banks every 3 to 4 years. Still, the Legislator and the Regulator make reference to the need to strengthen capital base of banks and their compliance with the recommendations of the Basel Committee on Banking Supervision. However, the recommendations of the Basel Committee do not contain any requirements as to the absolute value of bank statutory capital. The requirements of these recommendations refer to bank capital adequacy and capital quality.

On the other hand, such a tradition contradicts the generally accepted legitimacy principles (denies the so-called Grandfather's Clauses), as well as the elementary logic of economic feasibility and scientific principles of banking management, which presuppose that optimal size of a bank depends on the client base composition and therefore, economic and financial conditions of a particular region of service. For many years, the Bank of Russia and the Legislator have ignored the proposal of banking community to define the status of local and regional banks, which would allow the existing capable banks to continue their activities without the need of finding periodic solutions to puzzles, that is, where they need to find capital to increase the statutory fund. The tragicomedy of the situation lies in the fact that the story does not end with obtaining the required amount of money and further develops as a challenge, that is, where and how they need to place this additional capital, since the regional market and the operation areal of small banks are limited. At the same time, the opening of a subdivision of a major bank in such a limited areal is generally not profitable due to heavy overhead costs. As a result, due to the policy of consolidation of commercial banks, small regional banks get closed, and the population of large areas, including small businesses, lose banking services.

4) Creation and maintenance of a simple two-level banking system and the primitivism of its institutional structure.

In Russia, there exists a simple two-level banking system, consisting of the Central Bank and commercial banks, and excluding any variety of types, kinds or forms of banking institutions, which successfully operate in the banking systems of other countries. No reasonable explanation can be found for such irrepressible requirement of uniformity to banking system in such a huge country with a range of different geographic, cultural and economic conditions. As a result, official policy aims to develop small businesses conditioned upon the elimination of small commercial banks and total lack of cooperative banks; official policy aims to develop agricultural sector conditioned upon the lack of land banks; official policy aims to develop housing construction conditioned upon the 
lack of mortgage banks; official policy aims to implement innovative modernization of industries conditioned upon the lack of development banks; official policy aims to pursue intensive social policy conditioned upon the commercialization of Sberbank and the lack of ethnic banks, such as Islamic banks, etc. In the latest review of banking sector, prepared and posted on the website of the Bank of Russia, things came to a curiosity: in this review, all the essence and content of institutional development of banking system is reduced to enhancing its concentration. In our view, it is hard to imagine a more tragicomic situation for banking system and banking community.

5) Lack of strong and efficient enough group of development banks in banking system.

The adoption of the law on a development bank, according to which Vneshekonombank was transformed into a bank with special status and purpose in 2007, was the first step in this direction. Further development expressed in the transformation of Vneshekonombank into a separate banking group, which includes subsidiary commercial banks and is designed to support small and medium-sized businesses, can be considered a good start. However, if we evaluate the share of Vnesheconombank in the Russian banking system and compare its potential with the enormous tasks of modernizing the economy of the country, the lack of this potential becomes apparent. In conditions of large revenues from energy exports and the openness of markets for borrowings, and in the absence of any ambitious plans to modernize the economy, one could probably do without development banks. However, in conditions of limited financial resources and the need for real reconstruction of the economy, one cannot do without a powerful group of development banks. The experience of post-war Germany and Japan, or today's China, proves that.

We could probably expand the list of characteristic features of banking policy in Russia over the past two decades, emphasizing the dedication of the Bank of Russia to liberal monetary policy, its dependence on the Russian government policy, its continuous ignoring of strategic interests in the development of banking system and the economy in favor of current short-term effects, the of specialized foreign trade banks and other mechanisms of banking support for external economic activity of domestic businesses in banking system structure, the milking of financial resources of the economy to foreign countries, and the dependence of the Russian banks and companies on foreign borrowings, etc. Still, even the five above-mentioned characteristic features give us sufficient grounds for the evaluation of this policy as weak and inefficient. We come to the conclusion about the reasonableness of this evaluation, if we consider the external economic effects of this policy and its interrelation with external economic policy.

The reduction in number of small banks and the impossibility of their access to financial resources of the Central Bank of Russia, leads to the situation when many small and medium-sized businesses, participants of external economic relations, lose operational banking support. They line up in the subdivisions of major banks, awaiting decisions on small loans and guarantees. As a result of the primitiveness of the institutional structure of banking system and the lack of any variety of types and kinds of specialized banks, both banks and their corporate clients are deprived of the opportunity to establish various forms of industry-specific and sectorial links with their foreign partners and have to seek ways to circumvent requirements of Western banks in regard to loan granting. As a result of the lack of long-term financing sources in general, and the absence of a strong group of development banks in particular, major Russian companies and banks have to appeal to external borrowing sources and take high exchange risks. The events that took place in October this year vividly demonstrate what these risks turn into. Today's campaign of economic and financial sanctions against Russia manifestly shows where the dependence on external financing sources may lead.

On the other hand, fully commercialized state-owned banks are gradually driving private banks out of the market hampering their development and expansion. At the same time, the guidance of commercial management principles prevents them from consistent engagement in the financing of the investment projects significant for the economy and social life of the country. To use the capabilities of these banks, authorities have to fall back on administrative pressure methods. The response is expressed in the dissatisfaction of these banks and their claims to compensate the losses at the expense of the budget. After the Olympic Winter Games in Sochi, there appeared many publications in Russian mass media describing the losses of state-owned banks involved in financing the construction of the Olympic venues in Sochi. Why does this kind of situations arise? It doses just because the commercialization of state-owned banks:

a) Exposes these banks to objectively difficult circumstances when, after having imposed requirements as to their activities according to the market rules, they are required to solve non-market problems; 
b) Requirements to operate according to the market rules distort their essence significantly and turn them from means of implementing the state economic policy into means of the implementing the narrow corporate interests, sometimes with a noticeable strain of corruption.

A. V. Vernikov has had a good point about the contradictions in the nature of state-owned banks in Russia. In his widely-cited article "The share of state participation in the banking system in Russia" ("Money and Credit" Journal), he clearly points at the following qualitative condition of commercialized state-owned banks: "The state in general bears the burden of the recapitalization and liquidity support for such banks, without receiving any benefits from their ownership. Here is the privatization of profits and the nationalization of losses." (p. 11, No. 11, 2009.) Thus, the commercialization of banks in Russia turns them into quasi-state commercial entities and makes it possible to use them for national purposes in line with political will of top management: such will forces banks to obey, though they do not hide their displeasure with the circumstances which reduce the commercial efficiency of their activities; with the weakening of political pressure, commercial and corporate interests naturally prevail, in broad sense of this word.That is why banking community negatively evaluates the tendency of increasing the share of banks with the participation of and under the supervision of public authorities in Russian banking sector as a form of suppressing competition on banking services market. At the same time, such a tendency leads to the fact that the state loses the most efficient means of implementing its economic policy and cannot obtain any tangible results in the restructuring and diversifying of national economy and the necessary improvements in social development from year to year.

If we look at data from Table 2 showing the structure of financing sources for fixed assets investment in the post-Soviet countries, we may observe that the share of domestic banking sector is relatively high in the countries where specialized state-owned banks are preserved and state-owned development banks have been created. This group primarily includes such countries as Belarus, Uzbekistan and Kazakhstan. The analysis of the data from Table 4, which reflects the institutional structure of banking systems in the post-Soviet countries, also confirms the reasonableness of such conclusion.

Table 4. Institutional structure of banking systems

\begin{tabular}{|c|c|c|c|c|c|c|c|c|}
\hline \multirow[t]{2}{*}{ Country } & \multirow{2}{*}{$\begin{array}{l}\text { Total } \\
\text { banks }\end{array}$} & \multicolumn{3}{|l|}{ Including } & \multirow{2}{*}{$\begin{array}{l}\text { Total banks } \\
\text { with state } \\
\text { participation }\end{array}$} & \multicolumn{3}{|c|}{ Including } \\
\hline & & $\begin{array}{l}\text { Total with } \\
\text { foreign } \\
\text { participation }\end{array}$ & $100 \%$ & $\begin{array}{l}50 \% \\
+\end{array}$ & & $100 \%$ & $50 \%+$ & $\begin{array}{l}\text { Development } \\
\text { banks }\end{array}$ \\
\hline Russia & 859 & 251 & 76 & & 26 & & & 1 \\
\hline Ukraine & 180 & 49 & 19 & & & & & \\
\hline Kazakhstan & 38 & 17 & & & & 1 & & 1 \\
\hline Belarus & 32 & 22 & 8 & 14 & 4 & & & \\
\hline Azerbaijan & 43 & 22 & & 7 & 1 & & 1 & \\
\hline Uzbekistan & 27 & 4 & & & 3 & & & \\
\hline Armenia & 22 & 20 & 12 & 15 & 1 & & & 1 \\
\hline Tajikistan & 16 & 14 & 5 & & 1 & & & \\
\hline Kyrgyzstan & 22 & 10 & 5 & & & & & \\
\hline
\end{tabular}

Source: Banks of CIS countries. Overview 2013. Moscow. 2014.

As seen from Table 4, the largest number of state-owned banks is preserved in Russia, Belarus and Uzbekistan . In Azerbaijan, Kyrgyzstan, Tajikistan and Armenia, one bank is preserved with a significant share (over 50\%) of state participation. One development bank has been created in Russia, Kazakhstan and Armenia.

The analysis of historical process as to the creation and development of banking systems in the post-Soviet countries shows that all these countries have similar characteristic tendencies, the development and expansion of commercial banks segment, the commercialization of state-owned banks, the increase in the share of foreign commercial banks, the primitivism of institutional structure of banking system, which excludes any variety of specialized banks, the rarity of available specialized development banks that could become the power for structural reforms in the economy and social life. At the same time, distinct fluctuating tendencies of the world's financial 
markets and the growth of political risks expressed in the application of economic and financial sanctions against certain countries clearly demonstrate the need to move away from liberal and monetary banking policy. The post-Soviet countries need the banking policies that can mobilize all kinds of sources for financial resources and transform them into loan resources, which are so necessary for the innovative modernization of the economy.

\subsection{National Development Banks of Post-Soviet Countries}

The most efficient means for carrying out structural reforms and for the support of interstate associations of cooperation and integrated development are specially created development banks. International community has accumulated vast experience in creating both the special development banks of structural elements of large regional interstate associations and the development banks of individual countries for supportingthe international activities of domestic companies. Typical examples of development banks of regional associations include the European Bank for Reconstruction and Development, the Asian Development Bank, the African Development Bank, the Pan-American Bank for Cooperation, etc. Typical examples of development banks for the reconstruction of national economy in general and the support of international activities of national companies include the Reconstruction Loan Corporation (Germany), the Japanese Development Bank, Vnesheconombank of Russia, etc.

The first development institute of the post-Soviet space was the Kazakhstan Development Bank. In December 2000, President N. Nazarbayev signed the Decree No. 531 "Concerning the Kazakhstan Development Bank", under which the Bank was established. When creating the Bank, the world's experience in the operation of national and international development banks and the peculiarities of transitional economy of Kazakhstan were studied and taken into account. According to the Decree, the single founder of the Bank was the State Agency for Public Property Management. The progressive nature of the Decree determined the specific management structure of the Bank, which was created at the expense of public means and designed to support the implementation of public investment policy. In addition, the Bank received relative freedom in decision-making. This was an important factor for efficient operation of the Bank in the future. At all stages of the evaluation, projects need to meet high requirements as to their competitiveness, corporate and national efficiency. By now, the Bank has defined its niche in the financial sector of the Republic of Kazakhstan according to the following parameters:

- Meeting the investment needs in non-primary sector of the economy;

- Secondary sector, manufacturing and transport infrastructure;

- Large (over 30 million US dollars) capital-intensive investment projects with payback period of 5 to 20 years;

- Facilitation of goods export for manufacturers in Kazakhstan.

According to annual report, since the beginning of the Bank's activities, investment projects and export transactions totaling $\$ 14$ billion, with the participation of the Bank in the amount of $\$ 8$ billion, have been approved for financing. (Annual Report, p. 56.)

Table 5. Dynamics of the loans approved by the Development Bank of Kazakhstan, $\$$ billion

\begin{tabular}{ll}
\hline Years & Approved loans \\
\hline 2008 & 3.8 \\
2009 & 4.1 \\
2010 & 5.1 \\
2011 & 4.9 \\
2012 & 7.1 \\
2013 & 8.0 \\
\hline
\end{tabular}

Source : http://www.kdb.kz/ru/about/reports/ Revision Date 17.12.2014.

Recently, the Bank has developed and approved the perspective strategy which covers the period up to 2023.

In 2007 special federal law No. 82-FZ "Concerning the Development Bank" was adopted in Russia, which defined the new status of Vnesheconombank and the terms of regulating its activities. The Law defined the Bank's main purpose, which is to increase the competitiveness of Russia and its diversification by means of investment and external economic activity. The Bank is designed to finance investment projects aimed at infrastructure 
development and the implementation of innovation projects (Law No. 82-FZ, art. 3, para. 1-2). By now, Vneshekonombank Group has been established, which includes 16 subsidiaries of Vneshekonombank, aimed implementing the provisions of the above Law. According to financial policy memorandum, Vneshekonombank currently grants loans, guarantees and sureties for the projects with the payback period exceeding 5 years, total cost - over 2 billion rubles, the participation of the Bank —over 1 billion rubles. In current financial situation in Russia, where getting medium and long-term loans is still problematic, the activities of Vneshekonombank create a good perspective for financing large investment projects. Table 6 shows basic indices of the Bank's activities over the recent years.

Table 6. Main indexes of Wheshekonombank compared to the Russian banking system

\begin{tabular}{lllllllllll}
\hline Indexes & \multicolumn{2}{l}{$\begin{array}{l}\text { Semester I2014 } \\
\text { Billion } \\
\text { rubles }\end{array}$} & $\begin{array}{l}2013 \\
\text { Billion } \\
\text { rubles }\end{array}$ & $\%$ & $\begin{array}{l}\text { Billion } \\
\text { rubles }\end{array}$ & $\%$ & $\begin{array}{l}\text { Billion } \\
\text { rubles }\end{array}$ & $\%$ & $\begin{array}{l}\text { Billion } \\
\text { rubles }\end{array}$ & $\%$ \\
\hline Assets & 3,446 & 5,61 & 3,314 & 5,77 & 2,919 & 5,89 & 2,532 & 6,08 & 2,043 & 6,04 \\
Liabilities & 2,868 & & 2,737 & & 2,387 & & 1,999 & & 1,548 & \\
Capital & 579 & 7,86 & 577 & 8,17 & 532 & 8,70 & 533 & 10,07 & 495 & 10,46 \\
Loans & 2,388 & 5,62 & 2,139 & 5,29 & 1,691 & 4,98 & 1,392 & 4,85 & 932 & 4,21 \\
\hline
\end{tabular}

Source : http://veb.ru/about/vebgroup/ Revision date 17.12.2014.

\subsection{Regional Development Banks Established with the Participation of Post-Soviet Countries}

In this context, the establishment of the Eurasian Development Bank became a very important step forward on the part of Kazakhstan and Russia. Later, Armenia, Kyrgyzstan and Tajikistan joined this project. The Eurasian Development Bank became the first development bank jointly created by the post-Soviet countries for financing development and mutual integration projects. The joint-venture bank "Sodruzhestvo", previously created by the CIS countries, was intended to contribute to the development and integration of these countries. At that, its main purpose was to ensure the establishment of interstate trade and economic links. However, the Sodruzhestvo Bank did not manage to achieve any significant results in any area.

Since its foundation, the Eurasian Development Bank has been focused on financing projects in real sector economy in the countries of the Customs Union, and thereby it received correct guidelines for the implementation of its mission and the success of its activities in the long term.

Table 7. Country-based structure of current investment portfolio of the Eurasian Development Bank

\begin{tabular}{llll}
\hline Total & $100 \%$ & $3,882,054,000$ & \\
\hline Russia & 45.18 & $1,753,802,000$ & 23 \\
Kazakhstan & 36.76 & $1,426,829,000$ & \\
Belarus & 12.58 & $488,473,000$ & 9 \\
Armenia & 1.57 & $61,000,000$ & \\
Tajikistan & 0.38 & $14,897,000$ & \\
Kyrgyzstan & 0.9 & & \\
Others & 2.63 & & \\
\hline
\end{tabular}

Source: http://www.eabr.org/r/about/status/ Revision date 17.12.2014.

The analysis of the Bank's activities during the first years of its existence allows us to estimate the peculiarities of strategies and policies of the Bank and make certain assumptions about the efficiency of these activities in the future. On the one hand, in the documents that define the strategic directions of the Bank's activities, we can clearly see the Bank's attention to the implementation of the integration function entrusted to the Bank by its founders. In this regard, the work of the Integration Research Center established and functioning as the subdivision 
of the Bank is of particular interest. Interesting projects of the Centre itself and reports prepared on its request and with its coordinating role as to the challenging issues of the Eurasian integration, in-depth discussion of this range of challenges in a variety of forms (from round tables to international conferences), and the publication of special magazine "Eurasian Integration" create solid scientific and analytical basis and practical guidelines both for the Bank and for a wide range of scientific community. Unfortunately, in its main projects the Center adheres to the concept of mechanical copying of the European Union's model for the Eurasian Economic Union, the fact that in a way brings into a question the scientific value of these projects and makes them look like the attempts to justify the unsound and unreasonable political order.

Another problem is observed when analyzing the package of projects approved by the Bank for financing: most of these projects are separate projects for the development of Russian and Kazakh businesses, without any distinct integration effect. Such approach to the selection of projects for financing and crediting may limit the efficiency of the Bank's activities. Due to the ongoing and growing investment hunger in all countries of the former Soviet Union, the Bank's potential may be dispelled and reduced to nothing because of this approach. Therefore, it would be better to focus on the projects with a distinct integration effect. These projects would simultaneously serve as development projects for the countries participating in the integration. (Burakov, 2014a; 2014b)

We would like to emphasize once again the two criteria critical for the evaluation of a project financed by the Bank and the Bank's loan portfolio:

a) Integration effect of a separate project and the portfolio of projects for the participants of the association;

b) Contribution to the development of economy and social welfare for the group of member countries.

That is why the activities of the Eurasian Development Bank and any other bank claiming certain role in integration processes should be assessed primarily on the basis of above-stated criteria. All other indices can be assessed only in terms of the overall performance of the Bank.

It should be noted that the establishment of special banks aimed at integration development is not the guarantee of success or panacea for meeting all challenges of integration. The point is that the role and function of a development bank can be performed by any capable commercial bank, not to mention a state-owned bank, as it gets the respective powers and resources. The availability of a certain program in a particular area of integration development and its resource support is the determining factor. If there is no specific program with clearly prescribed parameters, no specific task can be assigned to a special development bank or commercial bank.

While representing the Group of International Bank of Azerbaijan at the Business Center of CIS Economic Development and the CIS Financial and Banking Council for a few years, we made proposals from time to time with regard to financing the project of "North-South" transport corridor and the establishment of the Caspian Development Bank as primary and guiding steps towards real integration of the Caspian bordering countries. We are convinced that only the development and implementation of such specific programs can ensure real integration of the countries in this region, regardless of whether they formally take part in any association or not.

Another regional development bank, in which a large group of the post-Soviet countries participates and cooperates, is the Black Sea Trade and Development Bank. The participants of this Bank include Russia, Ukraine, Moldova, Georgia, Armenia and Azerbaijan. These countries have participated in the formation of the Bank's capital and have quotas for financing projects in their own territories.

Table 8. Financing of Post-Soviet countries by the Black Sea Trade and Development Bank

\begin{tabular}{llll}
\hline Countries & Board Approved & Signed & Distr \\
\hline Azerbaijan & $241,277,204$ & $191,514,219$ & $220,131,539$ \\
Armenia & $150,499,869$ & $110,249,150$ & $120,425,811$ \\
Georgia & $103,377,336$ & $92,198,799$ & $138,350,507$ \\
Moldova & $92,537,892$ & $601,079,035$ & $59,013,641$ \\
Ukraine & $399,009,919$ & $343,934,548$ & $341,495,354$ \\
Russia & $791,184,854$ & $633,755,342$ & $649,895,090$ \\
\hline
\end{tabular}

Source: http://www.bstdb.org/countries/ Revision date 17.12.2014. 
As can be seen from the above, the post-Soviet countries, since the establishment of the Black Sea Trade and Development Bank, have been making use of certain capabilities of the Bank. However, limited resources of the Bank at initial stage and the intensification of political contradictions between the members of the Bank in the future became constraining factors with regard to successful cooperation.

\subsection{Cooperation of Post-Soviet Countries with International Development Institutions}

The Islamic Development Bank became a new development institution, with which a group of the post-Soviet banks has been developing cooperation over recent years. At present, the Bank actively supports projects in all Central Asian countries and Azerbaijan.

Table 9. Project financing and technical support by the Islamic Development Bank in post-Soviet countries (1976-2013)

\begin{tabular}{ll}
\hline Country & Total, million dollars \\
\hline Azerbaijan & 1040.4 \\
Kazakhstan & 534.7 \\
Kyrgyzstan & 192.0 \\
Tajikistan & 270.0 \\
Turkmenistan & 587.0 \\
Uzbekistan & $1,238.6$ \\
\hline
\end{tabular}

Source: http://www.isdb.org Revision date 17.12.2014.

The Islamic Development Bank operates in member countries on the basis of elaborating medium-term partnership strategies. The purpose of these strategies is to harmonize the activities of the Bank with the most important objectives of economic and social development in a member country. Strategy elaboration stimulates extensive research of development opportunities and determination of priorities for medium-term periods. These priorities are selected through dialogue among the authorities, public organizations, private sector, and financial institutions. These matters are also discussed by other development institutions operating in a particular member country. (Annual Report, p. 5) Over the past few years, the strategies elaborated by the Bank have been aimed at achieving certain results in member countries in the following main areas: the improvement of living standards and the creation of human capital; infrastructure investment; agricultural sector development and food security; the strengthening of economic cooperation and integration; the strengthening of Islamic finances, etc. (Annual Report)

The Asian Development Bank is another international development institution that has launched its activities in some post-Soviet countries. Table 10 below contains the summarized data as to the investments and guarantees by the Asian Development Bank in the Post-Soviet countries.

Table 10. Total investment by the Asian Development Bank in the post-Soviet countries (as of 2013, million dollars)

\begin{tabular}{lll}
\hline Country & & \\
\hline Azerbaijan & 637.40 & 20 \\
Armenia & 752.56 & 18 \\
Kazakhstan & $3,243.1$ & 29 \\
Kyrgyzstan & $1,251.2$ & 55 \\
Tajikistan & $1,127.31$ & 38 \\
Uzbekistan & $4,059.9$ & 53 \\
\hline
\end{tabular}

Source: http://www.adb.org/countries/ Revision date 17.12.2014.

The Bank operates in the respective countries based of five-year partnership strategies. For example, after Azerbaijan has become a member of the Bank in 1999, partnership strategy for the period of 2001 to 2006 was 
developed and approved for this country in the subsequent year 2000. At present, new partnership strategy for the period of 2014 to 2018 is under development. The peculiarity of this strategy lies in the fact that it takes into account the achievements of the country over the past decades. In particular, the Bank has ascertained the transition of Azerbaijan from the status of a low-income country to the status of a middle-income country, which excludes the possibility of obtaining any means from the Asian Development Fund. That is why the new strategy defines target activities to facilitate the achievement of high-scale objectives set forth in the state program "Azerbaijan 2020: vision of the future".

Even before that time, the change as to the quality of the Bank's partnership with Kazakhstan was observed. This happened in 2012, when Kazakhstan, for the first time ever, contributed 5.49 million US dollars to the Asian Development Fund as a donor. Up to this point, since 1994, when Kazakhstan became a member of the Bank, the country has been provided with the support in different forms every year. By 2013, total size of loans granted to Kazakhstan was 3.2 billion US dollars. At present, the Bank keeps providing the support for Kazakhstan in strategically important areas for future development. This includes the improvement of transit capabilities, the integration into global transport network, the development of logistics, etc. The Bank keeps rendering the support to small and medium-size businesses through loans to public sector and providing liquidity to the banks of Kazakhstan. The important area of the cooperation with the Bank is the improvement of energy efficiency in the economy of Kazakhstan. (Burakov, 2014c)

Among international and regional development institutions, activities of the European Bank for Reconstruction and Development cover almost all post-Soviet countries. The Bank has already accumulated vast experience in cooperation with the Post-Soviet countries, has financed a large number of projects and rendered technical support in reforming the economies of these countries.

Table 11. Project financing by the European Bank for Reconstruction and Development in the Post-Soviet countries (as of August 31, 2014, million EUR)

\begin{tabular}{llll}
\hline Country & Accumulated investment & Investment portfolio & Operating assets \\
\hline Azerbaijan & $1,920.1$ & 837.1 & 529.7 \\
Armenia & 730.9 & 277.6 & 216.1 \\
Belarus & $1,502.4$ & 584.3 & 463.5 \\
Kazakhstan & $4,958.4$ & $1,561.3$ & $1,099.4$ \\
Kyrgyzstan & 487.5 & 237.2 & 147.9 \\
Russia & 24,700 & 8,100 & 6,600 \\
Tajikistan & 341.0 & 155.9 & 56.9 \\
Uzbekistan & 740.2 & 32.0 & 31.7 \\
Украина & $9,543.2$ & $4,772.9$ & $2,762.1$ \\
Georgia & $2,093.7$ & 599.8 & 404.5 \\
Turkmenistan & 189.8 & 47.1 & 41.9 \\
\hline
\end{tabular}

Source: http://www.ebrd.com/ Revision date 17.12.2014.

Currently, the Bank operates in the member countries based on elaboration and implementation of medium-term (3 years) strategies. On April 30, 2014, the Bank's Board of Directors approved new strategy for Azerbaijan for the period of 2014 to 2017. The strategy has been elaborated on the basis of analysis as to the achievements of the country over the past years and the plans for future development. Its priorities correspond to the strategic objectives of the policy of the Azerbaijani government aimed at diversification of the economy, accelerated development of non-oil sector, agricultural regions, and the strengthening of financial system in order to ensure sustainable development of private sector. To implement these priorities, the Bank focuses on the following main areas:

1) Contribution to the diversification of the economy by using market methods. To do this, the Bank will support major local companies, small and medium-size businesses, both directly and in conjunction with local banks. 
2) Development of financial sector, maintaining its sustainability to support private sector development. The Bank will support its partners in financial sector to improve service standards, risk management and the development of healthy competition. The Bank will support the development of local capital market and the expansion of the use of new financing instruments.

3) Contribution to improving the quality of public administration management. The Bank will support primarily businesses of public and private sector, which adhere to high standards of corporate culture management and openness. The Bank will maintain links with authorities in deepening institutional reforms, in creating favorable investment climate. The Bank also intends to collaborate with international financial institutions and European institutions to intensify reforms and maximize their results.

The first financial development institutions, which rendered technical and financial support in the reforming and developing the national economies of the post-Soviet countries, were the International Monetary Fund and the World Bank Group. Currently, the post-Soviet countries keep actively collaborating with the IMF and the World Bank.

Table 12. The summarized data on loans/credits and guarantees by the World Bank Group (as of September 30, 2014, US mln. dollars)

\begin{tabular}{lll}
\hline Country & IBRD & IDA Credits/grands \\
\hline Azerbaijan & 1340 & 985,1 \\
Armenia & 3386 & 1330 \\
Belarus & 622,3 & 0 \\
Kazakhstan & 3716 & 0 \\
Kyrgyzstan & 779 & 77,5 \\
Moldova & 156,2 & 570,2 \\
Russia & 3440 & 0 \\
Tajikistan & 361,2 & 67,3 \\
Uzbekistan & 509,6 & 332,7 \\
Ukraine & 5639 & 0 \\
Georgia & 483,2 & 1426 \\
Turkmenistan & 21,1 & 0 \\
\hline
\end{tabular}

Source: http:www.data.worldbank.org/country/ Revision Date 17.12.2014.

The World Bank Group operates in the member countries based on elaboration and implementation of a specific support strategy. This strategy includes selective activity programs of the World Bank Group's organizations in a particular country. The strategy is elaborated by the Bank's employees in cooperation with public officials, representatives of civil society and the Bank's partners in the implementation of individual programs in a particular country. However, the main guideline of a country is always its own vision of the development. Thus, the World Bank Group's advantages compared to other donors and the coordination of all donors in a specific country are taken into account. The strategy sets forth the key areas, in which the World Bank Group's participation can yield the greatest results.

\section{Conclusion}

Despite some similarity in objectives, each of these organizations performs its own specific tasks, which determine the extent of their participation in social and economic development of the post-Soviet countries.

What is the significance of the cooperation with these international development institutions? In general, such cooperation is an important factor in solving social and economic problems of the post-Soviet countries and has diversified impact on their development. Let us emphasize some areas of this impact:

- In conditions of investment hunger and the abundance of problems accumulated in social and economic development, international development institutions provide necessary financial resources for investment, 
- These institutions assign financial resources for investment, as well as contribute to attracting capital from a variety of sources;

-International finance institutions not only contribute to attracting capital, but also take part in creating favorable environment for attracting and using investment resources. In this regard, technical support by international finance institutions in shaping market conditions and market infrastructure in the post-Soviet countries is of particular importance;

-Methodological training of national staff (officials, bank employees, etc.) in the adoption and use of methodological developments of international finance institutions in the analysis of development problems, elaboration, financing and implementation of projects, is of primary importance.

Analysis shows that both the developing and strengthening a group of national development banks and active cooperation with an international development institution are equally important for ensuring the sustainability of social and economic development of the post-Soviet countries.

\section{References}

Banks of CIS countries. (2014). Overview 2013. Moscow.

Burakov, D. V. (2014a). Credit Cycles \& Debt Restructuring: Refining Theoretical Flaws. Review of European Studies, 6(4), 1-11. http://dx.doi.org/10.5539/res.v6n4p1

Burakov, D. V. (2014b). Do Methods of Estimation Affect Credit Risk Osccillations? Mediterranean Journal of Social Sciences, 5(20), 114-120. http://dx.doi.org/10.5901/mjss.2014.v5n20p114

Burakov, D. V. (2014c). How to Measure Herd Behavior on the Credit Market? Mediterranean Journal of Social Sciences, 5(20), 516-521. http://dx.doi.org/10.5901/mjss.2014.v5n20p516

Harvard school of economy. (2011, December 08). Working Paper 12-047.

Ismaylov, E., \& Papava, V. (2012). Globalization and Central Coucazus. Washington

Johannes, F. L. (2011). Realizing the Potential of the Multilateral Development Banks.

Kharon, S. (2012). Islamic finance and banking system. Mirovoye-Media. Kazan.

Lavrushin, O. I. (Ed.). (2014). Sustainability of banking system and development of banking policy. Moscow: Knorus.

Raj, M. D., \& James, R. V. (2014, July 17). What the new bank of BRICS is all about? Washington Post.

Safarov, A. M. (2013). Modernizing society in CIS countries: Banking, economic and socio-political challenges. (Featured articles, reports, interviews). Moscow: Grif \& Co.

Sergio, G. L., Aldo, M., Rodrigo, B.-M., \& Rosilene, M. (n.d.). What Do Development Banks Do? Evidence from Brazil, 2002-2009. IMF papers.

Statistical Committee of CIS. (2014). Finances investment and prices of the Commonwealth of Independent States. Statistical abstract. Moscow.

The future of development banks. (2012. September 24). Special report of Financial Times.

The Stieglitz's Report: Reforming the International Monetary and Financial Systems in the Wake of the Global Crisis. (2012). International Relations. Moscow.

Vernikov A. V. (2009). The share of public participation in the Russian banking system. J. Money and Credit, 11, 4-14.

http://www.worldbank.org/

http://www.ebrd.com/home

http://www.adb.org/

http://www.isdb.org

http://www.eabr.org/

http://www.bstdb.org/

http://www.kdb.kz/ru/about/about/

http://veb.ru/

http://cbr.ru/ 


\section{Copyrights}

Copyright for this article is retained by the author(s), with first publication rights granted to the journal.

This is an open-access article distributed under the terms and conditions of the Creative Commons Attribution license (http://creativecommons.org/licenses/by/3.0/). 